\title{
Wpływ szkoleń na znajomość metod leczenia bólu przez pielęgniarki pracujące w hospicjum
}

\section{The influence of training on the use of methods of pain treatment used by nurses working in hospice}

\author{
MARZENA CHWIAŁKOWSKA ${ }^{1,2}$, NINA MORAWSKA ${ }^{3}$ \\ ${ }^{1}$ Instytut Nauk o Zdrowiu, Państwowa Uczelnia Zawodowa we Włocławku \\ 2 Wojewódzki Szpital Specjalistyczny we Włocławku im. bł. ks. J. Popiełuszki, Oddział \\ Pulmonologii, Diagnostyki i Leczenia Raka Płuc \\ ${ }^{3}$ Centrum Medyczne Grupa Zdrowie w Kraszewo Czubaki 23a
}

DOI: http://dx.doi.org/10.21784/IwP.2019.016

ISSN: 2451-1846

\section{Streszczenie:}

Wstęp. Ból w chorobie nowotworowej jest znaczącym czynnikiem zwiększającym cierpienie, niepokój i zależność chorego od innych osób. Im dolegliwości bólowe są silniejsze, tym pacjent jest mniej samodzielny i wymaga większego wsparcia $w$ prostych czynnościach dnia codziennego. Zasadniczą rolę $\mathrm{w}$ procesie rozpoznawania i kontrolowania bólu odgrywa pielęgniarka, która spędza w hospicjum z pacjentem najwięcej czasu.

Cel. Celem pracy była ocena wiedzy pielęgniarek uzyskanej w czasie szkoleń w zakresie metod leczenia bólu.

Materiały i metody. Materiał do analizy stanowiły ankiety przeprowadzone wśród 50 pielęgniarek pracujących w Zakładzie Opiekuńczo Leczniczym Kraszewo Czubaki. Badanie zostało przeprowadzone $\mathrm{z}$ wykorzystaniem metody sondażu diagnostycznego.

Wyniki. Ponad $84 \%$ osób uczestniczących w szkoleniach twierdzi, że zna metody leczenia bólu. Natomiast ponad 83\% badanych, które nie brały 
udziału w formach kształcenia podyplomowego przyznaje, że nie posiada wiedzy w zakresie terapii bólu.

Wnioski. W wyniku przeprowadzonych badań ustalono istotny wpływ szkoleń na znajomość metod leczenia bólu przez pielęgniarki pracujące w hospicjum.

Słowa kluczowe: ból, hospicjum, wiedza

\begin{abstract}
:
Introduction. Pain in cancer diseases is a significant factor increasing suffering, anxiety and sufferer's dependence on other people. The stronger the pain, the more dependent the patients are. They recquire more help in everyday activities. Nurses play the key role in recognition and controlling the pain since they spend a considerable amount of time with patients in hospice.
\end{abstract}

Aim. The aim of this study was to assess the knowledge of nurses on pain treatment delivered in training on methods of pain treatment.

Material and method. The study used questionnaire carried out among 50 nurses working in Nursing Home facility in Kraszewo Czubaki. The study was conducted with the use of diagnostic survey.

Results. More than $84 \%$ of respondents participating in training claim that they are familiar with the methods of pain treatment. However, 83\% of respondents, who have not participated in any post-graduate training on methods of pain treatment, do not have sufficient knowlegde about methods of pain treatment.

Conclusions. The study showed that training has significant influence on the knowledge about methods of pain treatment used by nurses working in hospice.

Keywords: pain, hospice, knowledge

\title{
Wstęp
}

Ból jest zjawiskiem, które towarzyszy ludzkości od zarania dziejów. To czynnik, który jest nieodzownym elementem życia każdego człowieka. Ból jest naturalną reakcją organizmu, która informuje 
o nieprawidłowościach związanych z funkcjonowaniem ciała bądź działania zewnętrznych czynników uszkadzających.

Słowo ból wywodzi się z języka greckiego, w którym „poine" oznaczało karę, stąd w wielu kulturach słowo to wiązano z koncepcją ukarania i zemsty. Według Międzynarodowego Towarzystwa Badania Bólu - ból (łac. dolor) „jest to nieprzyjemne, zmysłowe i emocjonalne przeżycie towarzyszące istniejącemu lub zagrażającemu uszkodzeniu tkanki, bądź odnoszone do takiego uszkodzenia". Ból jest więc reakcją obronną organizmu, odczuciem subiektywnym, cennym objawem diagnostycznym, występuje jako objaw większości chorób. Jeżeli doznania bólowe są bardzo silne i trwają zbyt długo, jak np. w schyłkowym stadium choroby nowotworowej, ból traci swoją rolę diagnostyczną (jako czynnik ostrzegawczo-obronny) i staje się cierpieniem $[1,2,3]$.

Uczucie bólu stanowi informację o rozpoczętym lub będącym w toku procesie chorobowym. Stanowią dla człowieka przede wszystkim negatywne przeżycie, któremu towarzyszą doznania:

- fizyczne: wymioty, nudności, brak apetytu, ograniczenie aktywności fizycznej, zaburzenia rytmu czuwania i snu,

- socjalne: ograniczenia w życiu rodzinnym oraz społecznym,

- psychiczne: gniew, strach, lęk, depresja,

- duchowe: cierpienie.

W podstawowym ujęciu ból dzielimy na: ostry i przewlekły. Pierwszy z nich trwa do trzech miesięcy od momentu jego powstania, zaś drugi - więcej niż trzy miesiące i nie ustępuje mimo wygojenia się struktur tkankowych. Ból ostry jest dolegliwością, która trwa krótko i szybko przemija $[4,5,6]$.

Ból jest zjawiskiem subiektywnym i złożonym, a więc istnieją znaczne problemy z jego oceną. Dlatego też dużą wagę przywiązuje się wywiadom przeprowadzanym przez lekarzy i pielęgniarki. Pytania stawiane choremu powinny pozwolić uzyskać informację na temat lokalizacji bólu, przyczyn występowania oraz jego charakteru. Istotne 
znaczenie ma również poziom nasilenia bólu a także metody, które pozwalają go zredukować.

Zwalczanie bólu jest możliwe przy zastosowaniu metod farmakologicznych, jak i niefarmakologicznych. Farmakologiczne leczenie bólu prowadzone jest na podstawie podstawowych założeń trzystopniowej drabiny analgetycznej, która została opracowana przez Światową Organizację Zdrowia w 1986 r [7-12]. Drabina analgetyczna zakłada wdozenie farmakoterapii bólu w oparciu o trzy stopnie:

- I stopień - nieopioid +/- leki pomocnicze;

- II stopień - słaby opioid w połączeniu z I stopniem;

- III stopień - silny opioid w połączeniu z I stopniem.

Do najpopularniejszych metod leczenia niefarmakologicznego bólu zalicza się:

- blokady;

- techniki rehabilitacyjne;

- leczenie chirurgiczne;

- psychoterapię;

- techniki wspomagające.

Podstawowym błędem w terapii bólu jest nieumiejętność doboru prawidłowego programu leczenia niwelującego dolegliwości. Bardzo często zdarza się, że pacjenci otrzymują środki przeciwbólowe bez uwzględnienia ich uwag. Niekiedy leki podawane są drogą domięśniową zamiast drogą dożylną, co skutkuje ich wolniejszym wchłanianiem. Dolegliwości bólowe nie mogą być właściwie leczone bez dokładnego i wnikliwego rozpoznania, które stanowi integralną część procesu pielęgnowania, będącego podstawą pracy a zarazem obowiązkiem pielęgniarki. Konsekwencją rozpoznania bólu jest podjęcie właściwych czynności zmierzających do rozwiązania problemu. Identyfikacja bólu polega na obiektywnym i subiektywnym zebraniu informacji określających stan zdrowia pacjenta. Rozpoznanie bólu stanowi osobistą ocenę odczucia danej jednostki, które obejmuje również fizyczną, emocjonalną, behawioralną i poznawczą odpowiedź chorego na powyższe doznanie [4]. 
Celem podjęcia przez pielęgniarkę działań opiekuńczych w stosunku do pacjenta cierpiącego z powodu bólu powinno być wyeliminowanie lub zmniejszenie dolegliwości do poziomu akceptowanego przez chorego. W opanowywaniu bólu zespół pielęgniarski przykłada dużą wagę do czynników zewnętrznych, psychicznych i duchowych wpływających na odczuwanie dolegliwości. Pielęgniarka powinna znać i umiejętnie przekazywać niezbędne informacje na temat mechanizmów bólu i jego źródeł w chorobie nowotworowej[13]. Dostosowując zakres wiadomości, ich formę i język do możliwości poznawczych chorego, pielęgniarka zwiększa poczucie bezpieczeństwa pacjenta i buduje swój wizerunek jako profesjonalisty $\mathrm{w}$ pielęgnowaniu. Zaznajamiając pacjenta $\mathrm{z}$ metodami terapii bólu i możliwymi objawami ubocznymi, ułatwia mu zrozumienie stanu jego zdrowia, zmniejsza lęk, a przede wszystkim pomaga stać się aktywnym podmiotem leczenia. By móc podjąć zadania służące łagodzeniu dolegliwości bólowych, zespół pielęgniarski powinien znać narzędzia służące do oceny natężenia bólu [14].

\section{Cel pracy}

Celem pracy była ocena wiedzy pielęgniarek uzyskanej w czasie szkoleń w zakresie metod leczenia bólu.

\section{Materiały i metody}

Badania dotyczyły 50 pielęgniarek i pielęgniarza pracujących w Zakładzie Opiekuńczo Leczniczym w Kraszewo - Czubaki (hospicjum). W pracy wykorzystano autorskie narzędzie badawcze kwestionariusz ankiety, który zawierał 20 pytań służących weryfikacji wiedzy respondentów nt. leczenia bólu.

Respondentów podzielono na cztery grupy wiekowe, wśród których najliczniejszą tworzyły osoby między 34-45 rokiem życia (42\% badanych). Charakterystykę wieku badanych prezentuje Tabela 1. 
Tab. 1. Wiek badanych.

\begin{tabular}{|c|c|c|}
\hline Wiek & N & $\%$ \\
\hline $\begin{array}{c}25-35 \\
\text { lat }\end{array}$ & 15 & 30 \\
\hline $\begin{array}{c}34-45 \\
\text { lat }\end{array}$ & 21 & 42 \\
\hline $\begin{array}{c}45-55 \\
\text { lat }\end{array}$ & 6 & 12 \\
\hline $\begin{array}{c}55-65 \\
\text { lat }\end{array}$ & 8 & 16 \\
\hline Ogółem & $\mathbf{5 0}$ & $\mathbf{1 0 0}$ \\
\hline
\end{tabular}

W badaniu wzięło udział 50 osób, w tym 49 kobiety i 1 mężczyzna.

Ponad połowa badanej grupy (52\%) posiadała tytuł licencjata pielęgniarstwa, $28 \%$ osób - tytuł magistra pielęgniarstwa, natomiast $20 \%$ respondentów ukończyło liceum medyczne. Rycina 1 prezentuje wykształcenie badanych.

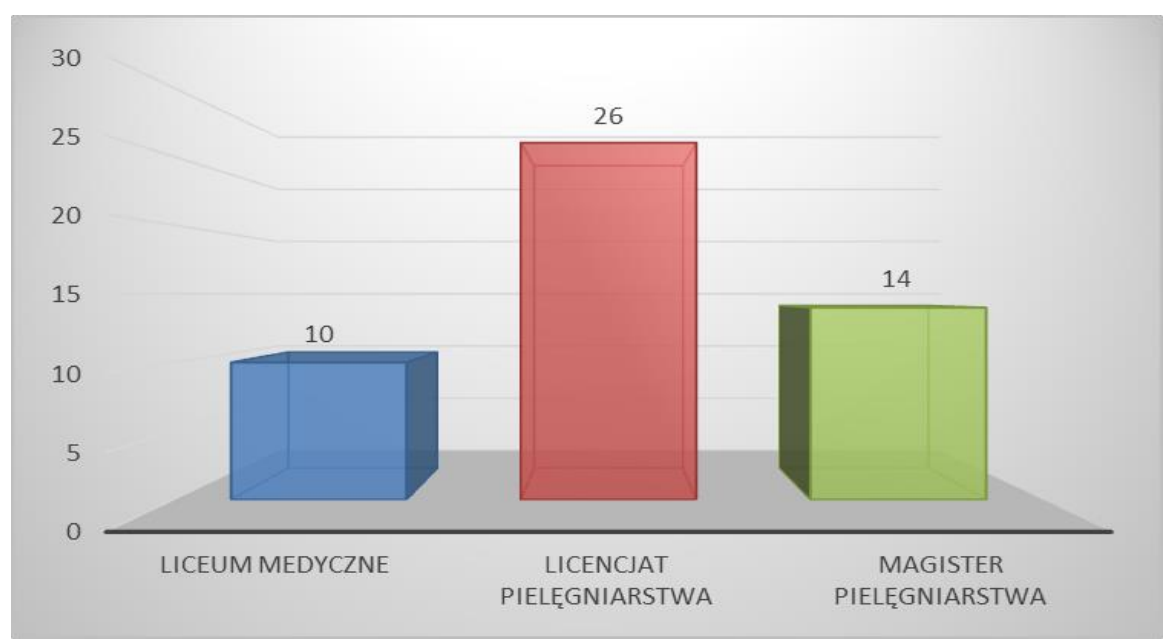

Ryc. 1. Wykształcenie badanych. 
Wśród respondentów zostały wyodrębnione cztery grupy z uwagi na staż pracy. Najliczniejszą grupę respondentów stanowiły osoby pracujące w zawodzie od 5 do 10 lat - 32\%, 24\% badanych posiadało staż $0-5$ lat, odpowiednio po $22 \%$ badanych pracowało w zawodzie 10-15 lat oraz 15 lat i więcej. Rycina 2 ilustruje staż pracy respondentów.

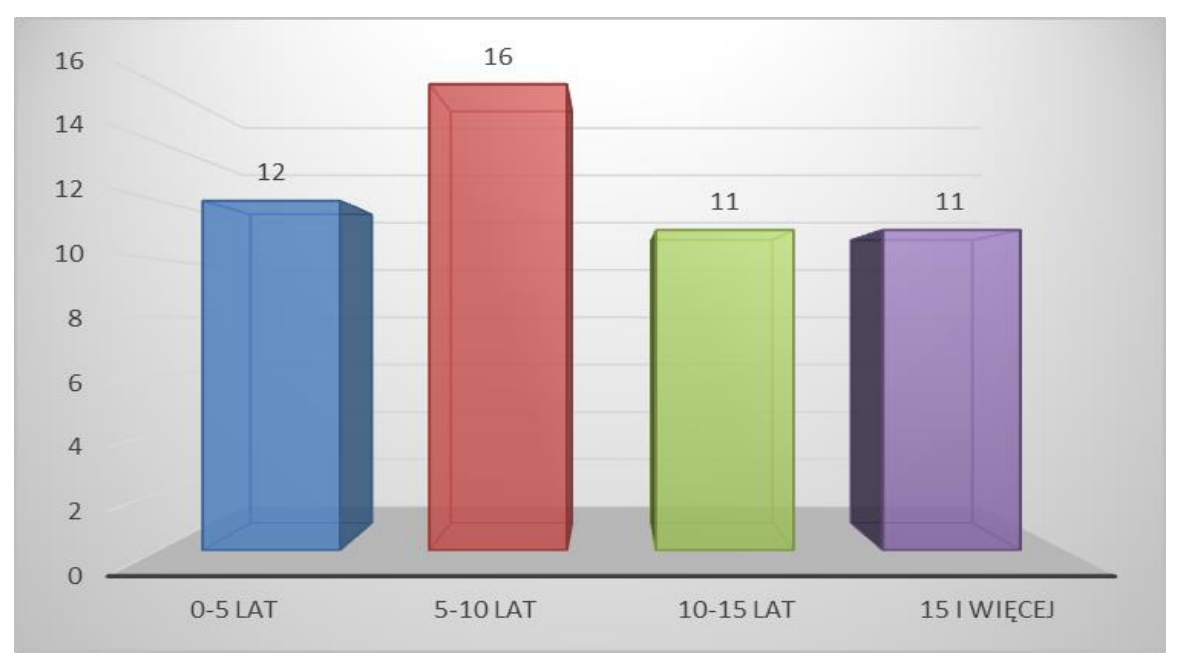

Ryc. 2. Staż pracy badanych.

\section{Wyniki}

Ponad połowa ankietowanych brała udział w szkoleniach na temat leczenia bólu (64\%). Natomiast 36\% badanych nie uczestniczyła $\mathrm{w}$ żadnym szkoleniu $\mathrm{z}$ tego zakresu. Rycina 3 przedstawia udział respondentów w szkoleniach. 


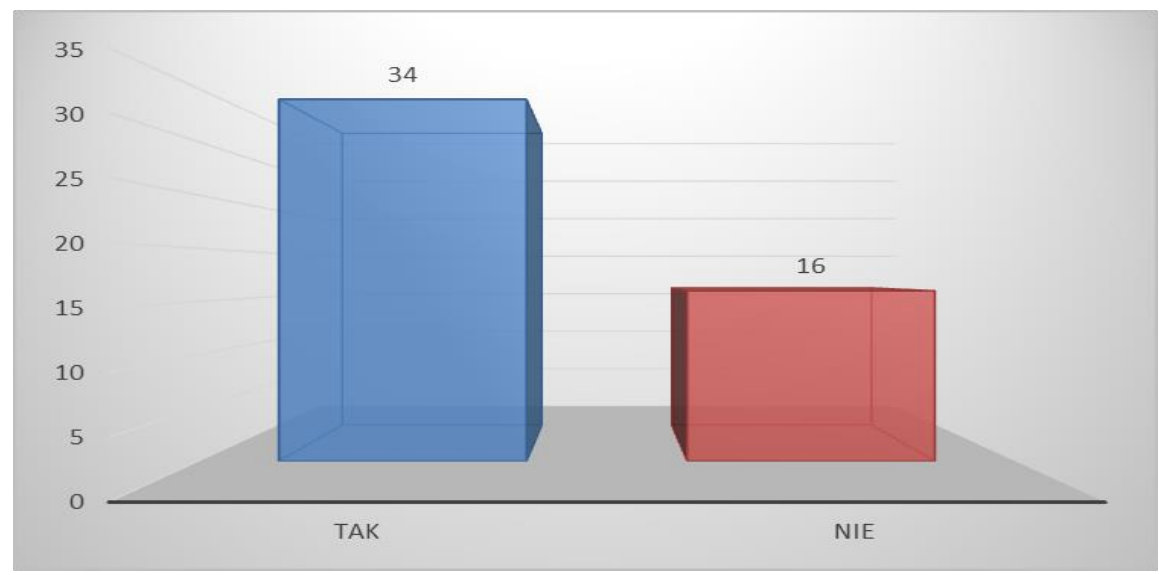

Ryc. 3. Udział badanych w szkoleniach na temat bólu.

Większość badanych (76\% osób) była zdania, że zna metody leczenia bólu. Odmiennego zdania było $24 \%$ osób. Opinie respondentów $\mathrm{w}$ zakresie posiadania wiedzy nt. terapii bólu przedstawia rycina 4.

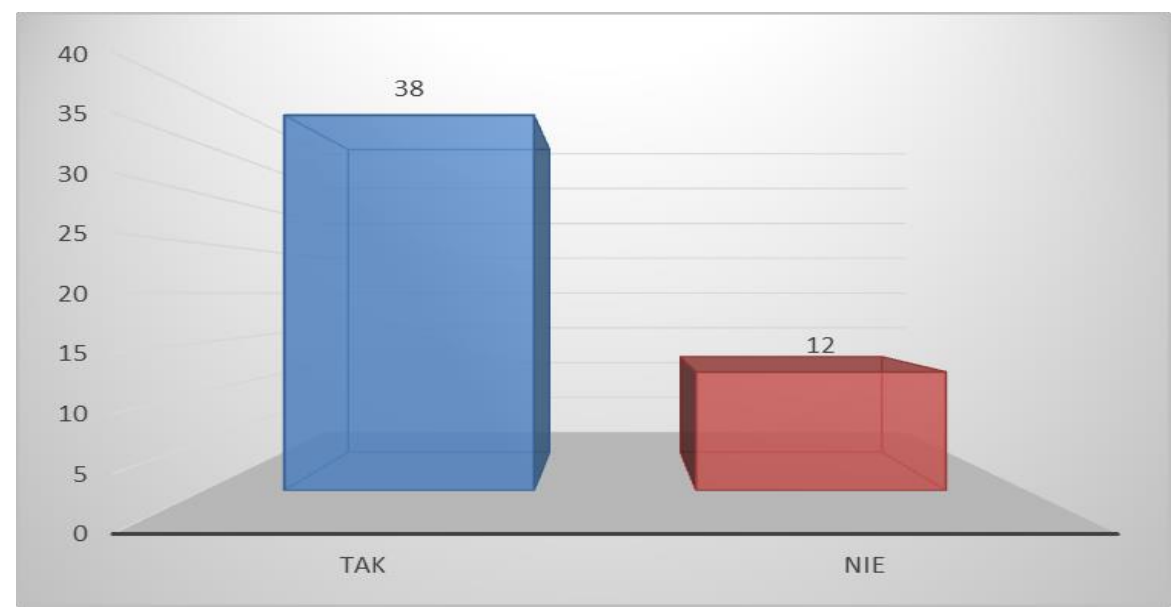

Ryc.4. Znajomość metod leczenia bólu w opinii badanych. 
Analiza statystyczna wykazała istotną zależność pomiędzy uczestnictwem w szkoleniach na temat leczenia bólu przez ankietowanych, a ich znajomością metod terapii. Ponad 84\% osób uczestniczących w szkoleniach twierdziło, iż zna metody leczenia bólu. Natomiast ponad $83 \%$ badanych, którzy nie brali udziału w szkoleniach przyznało, iż nie posiada wiedzy w tym zakresie, co prezentuje Tabela 2 .

Tab. 2. Znajomość metod leczenia bólu przez badanych a uczestnictwo w szkoleniach

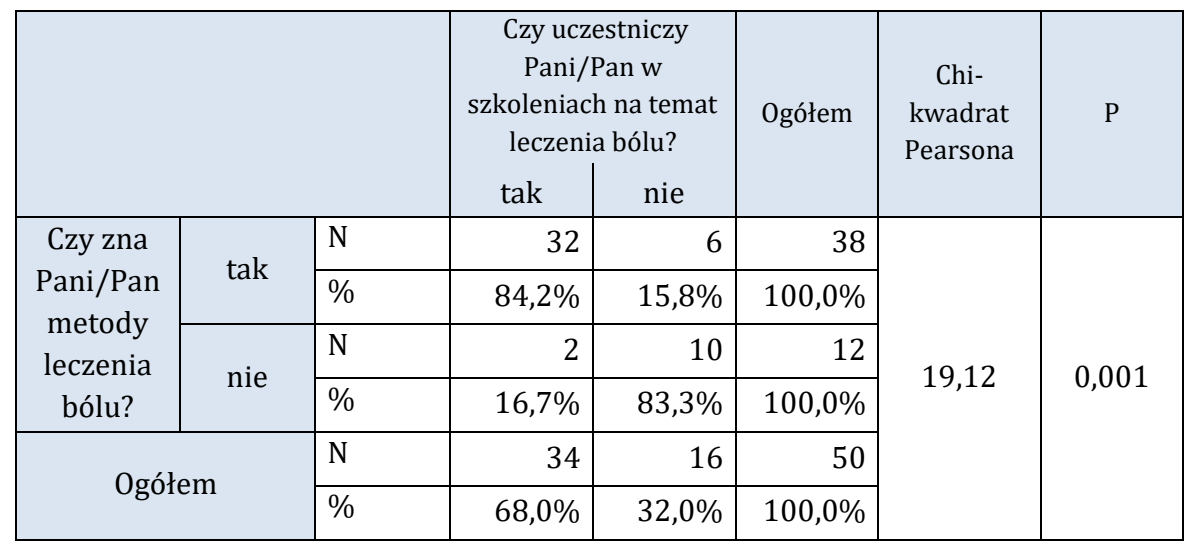

\section{Dyskusja}

Bardzo często dochodzi do sytuacji, w których ocena bólu odbywa się w oparciu o objawy obiektywne oraz analizę zachowań pacjenta. Jest to podstawowy błąd $\mathrm{w}$ ocenie dolegliwości bólowych. Koniecznym jest zwrócenie uwagi na subiektywne odczucia zgłaszane w tym zakresie przez chorego. Złe zdiagnozowanie bólu może skutkować podjęciem niewłaściwych metod leczenia [15].

W wyniku przeprowadzonych badań ustalono zależność pomiędzy uczestnictwem pielęgniarek w szkoleniach na temat leczenia bólu, a znajomością metod terapii $\mathrm{w}$ powyższym zakresie. 
Wyznaczony współczynnik korelacji w tym badaniu wynosi 19,12, co wykazuje bardzo silną zależność zmiennych.

Wrona i współautorzy zauważają, że nieustanne włączanie do specjalistycznych programów nauczania zasad oceny i monitorowania bólu przyczynia się do lepszego przewidywania przez pielęgniarki potrzeb pacjenta cierpiącego z powodu bólu w chorobie nowotworowej. Wykwalifikowany zespół pielęgniarski staje się rzecznikiem i przewodnikiem chorego na trudnej drodze leczenia, tak by mógł odnieść z niego jak największe korzyści [16].

\section{Wnioski}

W wyniku przeprowadzonych badań ustalono istotny wpływ szkoleń na znajomość metod leczenia bólu przez pielęgniarki pracujące w hospicjum.

\section{Zalecenia dla praktyki pielęgniarskiej}

Pielęgniarka powinna systematycznie podnosić swoje kwalifikacje zawodowe, aby prowadzić skutecznie monitorowanie i leczenie dolegliwości bólowych wśród pacjentów oddziałów hospicyjnych.

\section{Bibliografia/Bibliography:}

1. Hadjistavropoulos H.D., Craig K.D. Acute and chroniclowbackpain: cognitive, affective, and behavioraldimensions. J. Consult. Clin. Psychol. 1994;62:341-349.

2. Schwob M. Ból. Książnica. Katowice 1999;74-76.

3. Wordliczek J.. Dobrogowski J. Leczenie bólu. PZWL. Warszawa 2007;1107.Korzeniowska K., Szałek E. Ból. Farmacja Współczesna. 2010;3:9.

4. Loeser J.D., Treede R.D. Pain 2008;137,3:473-477. 
5. Steciwko A., Kurpas D. Podstawowe zasady leczenia ostrego i przewlekłego bólu w praktyce lekarza rodzinnego. Terapia. 2006;9:5360.

6. Dobrogowski J. Niefarmakologiczne metody leczenia bólu. Polski Przegląd Neurologiczny. 2007;3(4):272.

7. Dobrogowski J., Jassem J., Krajnik M., Wordliczek J. Stanowisko dotyczące postępowania przeciwbólowego u chorych na nowotwory. Medycyna Paliatywna w Praktyce 2009;2:88.

8. Dobrogowski J., Wordliczek J. Medycyna bólu. Medyczne Centrum Kształcenia Podyplomowego UJ. Kraków 2002;15.

9. Hilgier M. Bóle nowotworowe i ich leczenie. MCKP UJ. Kraków. 2002; 187-209.

10. https://www.doz.pl/czytelnia/a200-

Bol_przewlekly_nie_musi_byc_cierpieniem

11. Larysz A., Czapla K., Copik I. Ból jako piaty element życiowy. Magazyn Pielęgniarki i Położnej. 2013;6:40-41.

12. Puntillo K,, Wilkie D. Assessment of pain in the criticallyill. [w:] Puntillo K. Pain in criticallyill. Aspen Publishers, Gaithersburg 1991.

13. Wołowicka L., Marciniak R., Bartkowska-Śniatkowska A., Trojanowska I. czekiwania pacjentów w zakresie leczenia bólu okołooperacyjnego. [w:] Postępy pielęgniarstwa i promocji zdrowia. Cz.13. Wydawnictwo Akademii Medycznej. Poznań 1998;110-114.

14.Von Roenn JH., Cleeland CS., Gonin R., Hatfield AK., Pandya KJ. Physicianattitudes and practice in cancerpain management: A survey from the Eastern Cooperative Oncology Group. Ann Intern Med 1993;121-126. 
15. Wrona B., Janecki M, Fimiarzyc A. Wiedza pielęgniarek na temat aktualnych wytycznych leczenia bólu w chorobie nowotworowej, Medycyna Paliatywna 2014, 6(4):208-214.

Otrzymano: 29.10.2019r.

Zaakceptowano: 12.11 .2019 r. 